Зона В. Мркаљ ${ }^{1}$

Филолошки факултет

Универзитет у Београду

https://doi.org/10.18485/mks_knsjkk.2017.ch13

\section{ТИПОВИ КАРАКТЕРИЗАЦИЈЕ ЕПСКИХ ЈУНАКА У СТАРИЈИМ РАЗРЕДИМА ОСНОВНЕ ШКОЛЕ}

У раду се наводе и образлажу, увидом у примере из одабраних текстова народне и ауторске књижевности који се обрађују у старијим разредима основне школе, различити типови карактеризације епских јунака. Разматра се способност ученика узраста од 11 до 15 година да уоче начине на које писци врше карактеризацију ликова. Анализирају се различити начини поимања карактеризације у народној епици и ауторској прози. Образлаже се како облици казивања (форме приповедања), као један од кључних интерпретативних чинилаца, обликују карактере у приповеци или роману. Указује се на појмове психолошке, језичке, социјалне и етичке карактеризације и њихов удео у откривању идејног слоја текста.

Потреба за разумевањем поступка карактеризације доводи се у везу и са драматизовањем прозног текста. Проблематизује се однос појмова: лик јунак - тип - карактер - карактеризација, у сврху адекватног разумевања ових књижевних термина у настави и њиховог коришћења приликом тумачења књижевноуметничког текста.

Кључне речи: типови карактеризације, карактер, тип, лик, епски јунак, народна епика, ауторска проза, старији разреди, основна школа

Тумачење књижевних ликова само је један од елемената тумачења књижевног дела у настави, али је разумевање представљања различитих типова јунака у тексту често кључни чинилац у заснивању интерпретације. У композицији књижевноуметничког дела књижевни лик заузима важно место и у структурном и у семантичком смислу. Он је комплексан, сложен од више елемената на које се мора обратити пажња, како би наставна обрада литерарног предлошка и његово вредновање били ваљани. При анализирању естетских, етичких, идејних, тематских и других вредности дела, тумачење књижевног лика узима се као једна од неопходних и иманентних радњи, која ће подробно указати на све важне квалитете књижевног текста као целине.

mrkalj@ikomline.net
Формирање књижевног лика у свести читалаца непосредно зависи од способности сваког појединог читаоца (у нашем случају ученика) да књижевни лик посматра као обједињујући фактор наставне интерпретације, који се ослања на друге чиниоце тумачења. Типологија карактера непосредно се везује за литерарни жанр; структура књижевног дела и његове жанровске особености условљавају формирање и понашање ликова, док се избор теме и мотива непосредно може везати за њихово обликовање; идејни контекст директно нас усмерава ка доживљају који стичемо; језичкостилске особености „говора” јунака или приповедачеве сугестије о њему формирају читалачки поглед на карактер ликова и чине вештину разумевања прочитаног још комплекснијом.

Књижевни лик је увек двојако дефинисан: као релативно самосталан део целине која има сопствену организацију, али и као неодвојиви део текста као система у који је интегрисан и чијим је осталим елементима одређен. Њега је тешко разматрати независно од фабуле, јер представља организован систем особина, понашања, међуљудских односа, ставова, идеја, карактерних особина, темперамента, физичких карактеристика итд., на које истовремено делује сплет спољашњих утицаја и чинилаца.

Под књижевним термином „карактеризација” подразумевају се поступци помоћу којих су изграђени и представљени ликови у књижевноуметничким текстовима. Рашчлањујући, уочавајући и тумачећи етичке, идејне, социолошке и психолошке компоненте књижевног лика, ученици развијају сопствене етичке и естетичке критеријуме. Интерпретирањем психолошке и друштвеноисторијске мотивације, ставова и погледа на свет које одређени књижевни јунак заступа, тј. чији је носилац, ученици се подстичу да откривају односе међу ликовима, да их пореде, вреднују, образлажу њихове поступке, откривају разноврсне узрочно-последичне везе и тумаче експлицитне и имплицитне информације.

Значај проучавања типова карактеризације епских јунака² у настави српског језика и књижевности је широк. Карактериза-

${ }^{2}$ Синтагма ейски јунак овде се не односи на јунака епске народне песме, већ на јунака сваког прозног текста народне или ауторске књижевности. 
ција се мења према књижевном роду у којем се примењује (Поповић 2010: 329), а њена природа зависи и од поетичких захтева епохе. Стилски критеријум упућује на један од следећих типолошки условљених видова карактеризације лика: романтичарски, реалистички, натуралистички и модернистички. Романтичарски јунак је личност изузетних особина, снажних страсти и емоција, у сталном сукобу са светом. Реалистички јунак реализује се као карактер с индивидуалним цртама које су, истовремено, типичне за неку друштвену групу или слој којој она припада, односно коју у датом књижевном делу репрезентује. Његова карактеризација се најчешће остварује елементима говора јунака, спољашњих карактеристика, амбијента; класним и професионалним одликама. Као врста реалистичког наводи се често и натуралистички поступак који поменутим реалистичким елементима придодаје снажну физиолошку компоненту, биолошку мотивацију, нагоне и страсти. Модернистички приступ темељи се на поступцима који упућују на мисаону и психолошку слојевитост лика. У модерној прози свест, духовни свет, осећања, асоцијације, размишљања о свету - све су то важни елементи сложене концепције књижевног јунака. Њихова комплексност остварује се коришћењем различитих облика казивања, као што су: типови нарације; дијалози, монолози, унутрашњи монолози, портретисање, пејзажи и остали видови дескрипције, пишчеви коментари и други одговарајући приповедачки поступци ${ }^{3}$. Техника обликовања лика као критеријум тумачења подразумева да се књижевном лику приступа и са аспекта композиционих елемената књижевноуметничког текста.

Увидом у методичку праксу у српским школама, запажа се потреба да се у наставним оквирима додатно објасне књижевни

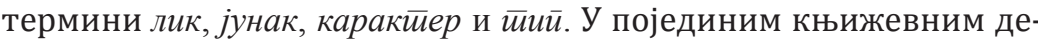
лима јунак може добити и статус хероја. У складу с тим, примећује се да се појму лик додељује највиши степен општости: ликови су и позитивни и негативни, главни, споредни, епизодни, позадински, они су и штеточине и помагачи, док јунак, у ученичкој свести, не може бити сваки лик. Он мора бити наглашено одређен својим карактером (и када је позитиван, и ако је негативан, и

${ }^{3}$ Више о овоме видети у: Диклић 1978 када је сличан нама), у складу с Аристотеловом типологијом. Те посебне особине јунака издвајају од осталих типова ликова који се у делу појављују.

Јунак се, према одредници у Нарайолошком речнику Џералда Принса (2011), одређује као протагонист или главни лик у књижевном делу и за њега се обично везују позитивне вредности. Иако јунак поседује негативне особине, он на неки начин мора бити привлачан и симпатичан публици. Могућност разврставања ликова на главне и споредне, динамичне и статичне, доследне и недоследне, плошне и рељефне (који се могу систематизовати и по одређеној улози или типу), везују се за јунаке по томе колико је представљен делокруг радње јунака или противника итд. У настави је значајно и разумевање термина лик, који се понекад користи и да означи приповедача (онога који приповеда) или наратера (онога коме се приповеда), док се, углавном, појмови карактер и лик узимају као синоними.

Како је у основној школи садржај програма из књижевности груписан по књижевним родовима, а у средњој школи успостављен према хронолошком редоследу појављивања литерарних остварења у различитим епохама и стиловима, то се савладавање улоге и значаја карактеризације у оквиру наставне интерпретације шири и на друге чиниоце тумачења. Тако се gирекйна каракиеризаиија, тј. поступак у којем аутор или нека друга личност у делу непосредно објашњава својства дате особе, везује за приповедање у којем се процењују јунакове способности, поступци и мотиви понашања, док се у иняирекииној каракиееризаиији карактер открива кроз поступке самог јунака, његово делање и говор. Мада се у тумачењу лектире, намењене ученицима старијих разреда основне школе више пажње придаје разумевању директног објашњавања јунака кроз описе и коментаре, онако како је аутор дела то осмислио, одабраним питањима и задацима подстиче

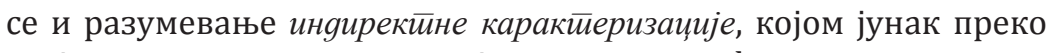
својих поступака открива своју природу и осећања.

У највећем броју случајева, у књижевним делима се јављају здружено два различита типа карактеризације: сйољашњ $а$ и унуйрашњ $а$, који су међусобно повезани: јунаков изглед, приро- 
да или окружење у непосредној су вези са његовим психолошким портретом. Посебан проблем који се може разматрати у вези са карактеризацијом јунака књижевног дела, тиче се и система мотивације целокупне активности лика (на пример, у случају дечака из Цанкарове приповетке „Десетица”). С обзиром на то да је књижевни лик, као и личност, увек спој система особина (спољашњих, унутрашњих, интерперсоналних, темперамента и сл.) и система друштвеноисторијских, културолошких, географских, климатских и других утицаја, важно је откривати шта је све утицало на формирање лика, као и на његово понашање и одлуке које доноси. Међутим, карактеризација варира и у зависности од идеја и васпитних ставова за које се залаже сам писац, од одлика стилске епохе у којој је стварао и од специфичности књижевне врсте, чиме се интерпретација вишеструко усложњава.

„Једног јесењег јутра пробудио сам се рано; тек је свитало, у соби је био сумрак. Соба је била велика, па ипак ми се тог јутра чинила уска и тесна, сва набијена и претрпана стварима, као при селидби. Уза зидове стајала су четири кревета, међу њима полице за књиге, велики дрвени ковчези који су личили на сандуке, ормани за одело, на средини огроман сто покривен књигама и свескама. Све је то у сумраку добило чудне, изобличене, некако непријатељске облике и чинило утисак неописиве беде и жалости" (Бајић, Мркаљ 2003: 13).

У Причи о кмейу Симану Иве Андрића удружују се елементи директне и индиректне карактеризације. Портрет књижевног лика и пејзаж који га окружује, карактеристике простора, превирања у души епског јунака служе као путоказ ученицима да о епском јунаку закључују и суде на основу његовог физичког изгледа, размишљања, осећања и поступања, као и путем анализе начина на који јунак говори и језика који користи, увидом у порекло и средину којој тај књижевни лик припада и његове моралне ставове (што све одговара структурној анализи лика).

„Први дани септембра. Сунчано јутро. У шљивику на трави лежи Симан, руке затурио под главу, над њим се мод- ре и савијају гране пуне рода. Не мисли ништа, само се смешка, јер га од главе до пете испуњава једно једино осећање: да је све ово његово. Као кроза сан чује доле шкрипу вратница и гласове. Погледа једним оком само, и одмах види шта је. Његов ага Ибрага, сарач, дошао са четири коња и једним момком да обере своју половину шљива. Симан га је пустио да му приђе посве близу, правећи се да га не чује и не види" (Несторовић, Грушановић 2016: 187).

Посебно занимљив тип карактеризације за ученике представља називање јунака према њиховим особинама (тзв. когномија). Овај пример препознаје се и код епских и код драмских јунака. На пример, у драми за децу Биберче Љубише Ђокића (где ликови носе следећа имена: Биберче, Добриша, Свадиша, Стогодан, Дивна, витез Страха, принц Кукавички, Звездан, Туњо, Грдило...), или у неким делима Бранислава Нушића и Стевана Сремца итд.

Физичка, а потом и психолошка карактеризација директног типа одређују се кроз описивање ликова и природе, дескрипцијом или нарацијом (као у примеру из приповетке „Аска и вук" Иве Андрића):

„Дивни предео, који је опијао и заносио Аску, дигао се одједном као танка и варљива завеса, а пред њом је стајао вук ужагрених очију, подвијена репа и као на смех малко искежених зуба, страшнији од свих мајчиних опомена. Крв се у Аски следила и ножице су под њом одрвенеле. Присећала се да треба да дозове своје, и отварала је уста, али гласа није било. Али смрт је пред њом била, невидљива а једина и свугдашња, грозна и невероватна у својој грозоти" (Несторовић, Грушановић 2012: 112).

Мада се у овом раду пре свега разматрају типови карактеризације епских јунака, тј. јунака који егзистирају у народној епици и у прозним делаима народне и ауторске књижевности, у основној школи је веома тешко разлучити начине формирања карактера епског јунака у односу на јунака драмског дела. Како се, на пример, у комедији карактера мане или пороци јунака сагледавају као основни покретачи драмске радње, ове комедије су на 
известан начин постављене и као психолошка интерпретација карактера и личности, са циљем како да забаве, тако и да поуче (уп. Поповић 2010: 364).

Док се комичност у драмским делима заснива на духовитим репликама, а донекле подстиче и у дидаскалијама, дотле се у прозном тексту, поред сликања епских јунака кроз дијалоге ликова, карактеризација јунака осликава и приповедачевим речима, а расположење ликова често се доводи у везу са описом природе која рефлектује душевно стање јунака. Разумевању особина јунака прозног дела доприносе и бројна језичкостилска средства. У народној епици, одличја јунака препознају се и преко предмета или бића која јунак поседује: бритка сабља, сиви соко, верна љуба, ђогат итд., уз које се обавезно уводе стајаћи епитети којима се јунак типски карактерише.

Занимљиво је колико на карактеризацију ликова утиче структура дела, тј. његова композиција. У основној школи се, ради лакшег разумевања прозног дела или народне епске песме, у оквиру стварања плана текста често прибегава одређивању назива целина према драмским елементима: експозиција, заплет, кулминација, перипетија, расплет. Ови елементи обавезно се везују за главног носиоца радње. Тако у Женияби Милића Барјакйара управо Милићева потреба да има оно што је најлепше и што највише жели, без обзира на опасност која се иза његове жеље крије (у овом случају урок), изазива заплет. „Основа за деловање карактера назива се мотивација, а поступци уз чију помоћ се они представљају назива се карактеризација" (Поповић 2010: 329).

Произвођење комичких или трагичких ефеката драме кроз ситуацију, карактеризацију и говор јунака у драми изазива другачију читалачку реакцију. Читалац „домишља” многа „празна” места, док су му у прозном тексту она детаљније објашњена.

Зависно од ученичких могућности на узрасту петог и шестог разреда, при интерпретацији књижевног дела у школи удружују се елементи директне и индиректне карактеризације, те се оваквим комбиновањем подстиче размишљање о узроцима и последицама нечијег понашања; откривају се разлози који могу представљати разрешења појединих поступака ликова и сл.
У читанкама, као најзначајнијим уџбеницима, у оквиру систематизације наставних садржаја повезаних са карактеризацијом ликова у епици, наводе се следеће врсте карактеризације према посебним и општим особинама лика:

1. физичка карактеризација - на основу описа физичког изгледа јунака;

2. психолошка карактеризација - на основу његових размишљања и осећања;

3. језичка карактеризација - на основу начина на који говори и језика који користи;

4. социјална (друштвена) карактеризација - на основу порекла и средине којој припада;

5. етичка карактеризација - на основу моралних ставова (Несторовић, Грушановић 2016: 190).

Познавање морално-психолошких особина лика ученицима омогућава поузданије разумевање идејног слоја књижевноуметничког текста и зарањање у богати уметнички свет литературе. Није редак случај да се различити типови карактеризације књижевних ликова преплићу (најчешће је то случај са психолошком карактеризацијом, у комбинацији с другим типовима) Одређивање физичке, социјалне и језичке карактеризације ученицима је знатно очигледније. У вези са тим наводимо и коментаришемо примере два задатка са такмичења „Књижевна олимпијада":

1. Одреди назив врсте карактеризације лика госпође Персе, као у датом примеру, на основу начина на који она испољава своја осећања, па одговор напиши на линији.

- Укр'о зуб! - понови госпођа Перса и скочи са столице и пљесну се рукама. - Доста ми је, доста! Немој ми казивати, нећу да те слушам! Боље главу да су ти украли. Нећу, нећу ништ' више да чујем.

Одговор на ово питање је „психолошка” карактеризација, али су ученици најчешће писали „језичка”. Ученицима-такмичарима, дакле, онима који су посебно заинтересовани за књижев- 
ност, у седмом разреду је још увек лакше да карактер јунака дела откривају преко начина на који се он изражава, него да уоче сву узнемиреност и узбуђење јунака (као у овом примеру), који се манифестују кроз описивање наглих покрета, узвичним реченицама.

2. Који тип карактеризације јунака препознајеш у следећем одломку из Сумњивоі лища? Заокружи слово испред тачног одговора.

Жика је дежмекаст, а велике чупаве главе, подбулих очију и дебелих усана. На њему виси извештало прљаво одело, прслук му кратак тако да му се кошуља под њим види. Панталоне му горе врло широке, а доле уске и спале те се наборале.

а) психолошка б) социјална в) језичка г) етичка

Одговор је непогрешиво код свих такмичара био „б) социјална” (карактеризација), што је, у суштини, тачно. Ученицима је неупоредиво лакше да преко физичког описа лика одреде његов материјални статус (Жика је сиромашан), него да претпоставе значење детаља којима се описује Жикина неуредност (алкохоличар је, депресиван, нема жену, усамљен је).

Типологија јунака везује се и за њихову појаву у различитим књижевним жанровима (у миту, басни, бајци, трагедији, комедији итд.). Књижевни лик чији карактер у себе сублимира особине одређене групе људи, на које утиче средина, историјски

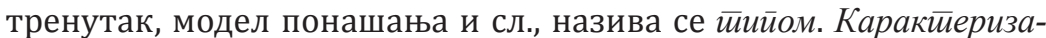
ција йийова увек се своди на истицање једне доминантне особине која се везује за групу људи коју тај тип представља. С овим у везу доводе се примери за схемайичку каракиеризаичиј, у којој лик постаје носилац наглашене позитивне, или негативне особине: Јања је тврдица, девојка је мудра, Еро је крадљивац, али и сналажљив, домишљат, Фема је уображена итд., додатно погодују мотивисању ученика да читању дела школске и домаће лектире приступе истраживачки и стваралачки, али и да уоче постојање типова у литератури још у основној школи.

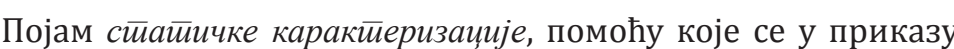
лика указује само на једну његову особину која је доминантна у његовом карактеру и не мења се, отвара врата поузданијем разумевању карактеризације ликова у народној књижевности. Пожељно је да се, на пример, уз поштовање аутономног света народне бајке, при интерпретацији откривају они елементи који су за бајку типични: кретање фабуларног тока, тумачење скривеног смисла необичних ситуација и чудесних трансформација јунака, типски јунак и сл. Тиме се афирмише темељно методичко начело у интерпретацији бајке - повезивање композицијске анализе с анализом ликова и идејног устројства бајке. У интерпретацији ликова узимају се у обзир још неки елементи који су карактеристични за друга приповедна епска дела: тумачењем тзв. „нестварних" ликова из биљног и животињског света уочавају се карактеристични стилски поступци: персонификовање, антропоморфизовање и хиперболичност. Те стилске црте добијају и своје идејно значење. Мада су ликови бајке „лаке, једнодимензионалне, папирне фигуре” (Лити 1994: 96) и не обавезују ни на какво одређено тумачење (или га чак и не допуштају), бајка допушта и тражи многа разноврсна тумачења, те оставља слободу читаоцу да, на пример, открива социјалну структуру ликова, као и мотивацију за поједине поступке, што се у доживљајном смислу може повезати са психологизацијом лика.

Како се у gинамичкој каракиееризащији лик приказује кроз развој, сазревање и промене (на пример, лик цара у народној новели „Дјевојка цара надмудрила”), управо познавање овог књижевнотеоријског појма нам помаже да боље разумемо специфичности одређеног литерарног жанра (у овом случају, народне новеле). Како се проблемски приступ поменутом тексту може засновати на анализирању поступака ликова у делу, запажа се да „основу решења представља антиципирање будућих догађаја и њихово разумевање, док се решавање проблема инвенцијом заснива на интуицији и оригиналности" (Мркаљ 2008: 64). Проблеми који се могу узети у разматрање су следећи: 
У којим је околностимма девојка стиекла муярости? По

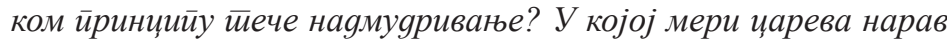

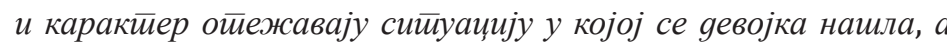
колико јој йоі̆оgују?Како се може објаснитии йојам чуgа у бајии и зачудносиии у новели? Зашйо је йреgвиђање йуђеї йонашања највећа муярости? По чему су ,, чуgа” у овој новели блиска бајичи, а чиме јој се суйройстиављају?

Разговор на часу поводом истакнутих питања открива за нимљиве нијансе карактеризације ликова цара и девојке. Мудра девојка прелази пут од просјакиње до царице тако што игра са царем својеврсну игру завођења. Посебно га привукавши својом интелигенцијом, храброшћу и оригиналношћу, девојка прихвата надметање мада јој цар даје немогуће задатке. Она их с лакоћом разрешава враћајући му истом мером. Својом промишљеношћу и предвиђањем догађаја одступа од народне мудрости да је љубав слепа. Приставши да се уда за цара, унапред се обезбеђује од његове плаховитости и исхитрености, чињенице да му је све дозвољено, изнудивши обећање да може, уколико је он отера, са собом да понесе из двора оно што јој је најмилије...

Разумевање различитих типова карактеризације може се увежбавати на часовима језичке културе, упућивањем ученика како да драматизују прозни текст, а потом га изведу на позорници. Одговарајуће примере оваквог поступања можемо видети у

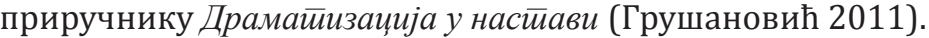

Типови карактеризације епских јунака, који се савладавају почев од старијих разреда основне школе, помажу ученицима да се у интерпретирање књижевноуметничких текстова у средњошколској настави укључе са предзнањем које значајно шири њихов поглед на књижевно дело и у себи сублимира свест о структури дела, његовим језичким специфичностима, карактеристикама књижевне епохе или правца и жанровских особености уметничког текста. Овакво предзнање као својеврсна синтеза усвојеног теоријског градива из књижевности поуздано служи као оруђе при сувереној наставној интерпретацији и доприноси дубљем разумевању прочитаног, то јест, ширењу читалачке перцепције.

\section{ЦИТИРАНА ЛИТЕРАТУРА}

Бајић Љ. Мркаљ З. По јуйру се gан йознаје (чийанка за йейи разреg основне школе). Београд: Завод за уџбенике, 2003.

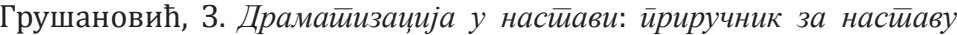
срӣской језика и књижевностии у основној и среgњој школи. Београд: Klett, 2011.

Мркаљ, 3. Насӣавно ирроучавање нарояних йрийовеgака и йреgања. Београд: Друштво за српски језик и књижевност Србије, 2008.

Несторовић 3. Грушановић 3. Чийанка „Корак” за шестии разреg основне школе. Београд: Klett, 2012.

Несторовић 3. Грушановић 3. Чийанка „Пуш"” за сеgми разреg основне школе. Београд: Klett, 2016.

Diklić, Z. Književni lik u nastavi. Zagreb: Školska knjiga, 1978.

Liti, M. Evropska narodna bajka. Beograd: Orbis, 1994.

Popović, T. Rečnik književnih termina. Beograd: Logos Art, Edicija, 2010. Prins, Dž. Naratološki rečnik. Beograd: Službeni glasnik, 2011.

\section{ТИПЫ ХАРАКТЕРИЗАЦИИ ЭПИЧЕСКИХ ГЕРОЕВ В СТАРШИХ КЛАСОВ ОСНОВНЫХ ШКОЛ}

В работе приводятся и обосновиваются различные типы характеризации эпических героев на примерах из отобранных текстов народной и авторской литературы, которые обрабатываются в старших классах основных школ. Расматриваются способности учеников возраста от 11 до 15 лет выявит каким способом писатель характеризует героев. Анализируются различные способы восприятия характеризации в народнойэпической и авторской прозах. Обосновивается каким способом формы высказвания (повествовательные формы), как один из ключевых интерпретационных способов, формируют характер в повестях и романах. Обращется внимание на понятия психолочической, языковой, социальной и этической характеризации и их роль в вывлении смысла идейного слоя текста.

Правильная тракторвка характеризации связываетсяс драматизацией прозного текста. Рассматриваетсяотношение понятий:образ-герой -тип - характер - характеризация в целяхправильного пониманияэтих литературных терминов в обучении и их использовании при трактовке литературного произведения. 